\title{
Educational Justice, Transformative Leadership Practices, and Special Needs Students
}

\author{
Gregory Minton ${ }^{1} \&$ M. Alayne Sullivan, ${ }^{2 *}$ \\ ${ }^{1}$ Redlands Unified School District, USA \\ ${ }^{2}$ University of Redlands, 1200 East Colton Ave., Redlands, CA, 92373, USA \\ *Corresponding author: E-mail: alayne_sullivan@redlands.edu
}

Received: July 20, 2013 Accepted: December 11, 2013 Published: December 23, 2013

doi:10.5296/ije.v5i4.4820ＵRL: http://dx.doi.org/10.5296/ije.v5i4.4820

\begin{abstract}
This mixed methods study investigated the extent to which transformative leadership (TL) practices of school administrators were considered with particular regard to special needs students in various public schools in Southern California. 26 purposefully selected school administrators rated the extent to which they employed a range of elements deemed prototypic of transformative leadership as derived from foundational texts of social and educational justice scholarship. Results of a quantitative survey questionnaire indicate a strong validation of a specific range of TL attitudes and behaviors, while qualitative interview data yields inclusive practice themes emphasized as important for working with special needs students. The study presents important realizations for male and female, and culturally diverse administrators as well as teachers who work with special needs students. As importantly, the survey generated for this study is an important measurement instrument for future research into transformative leadership values and practices.
\end{abstract}

Keywords: transformative leadership; educational justice; special needs students; equity 


\section{Background and Literature Review}

Taking the broad perspective, social and educational justice is an ontological construct and a series of reality-based acts that must be conceived from two perspectives. The first is a stance of ideological belief, an epistemological certainty of a worldview holding that we must offer fair and good educational chances for all students - we believe this and act to build such a world. The second point of view is pragmatic; it is action based, asserting that this is not the case for vast numbers of students. This level of realization prompts us to effect changes for the better good of vast numbers of students whose school lives are characterized by "savage inequalities" that make them the "shame of a nation" (Kozol, 1991; 2005). We now briefly explore the conceptual underpinnings of our theoretical belief in social and educational justice and the nuances of established work that aims to transform these inequalities, all the while keeping in mind the leaders of special needs students who emerge as central to the research being reported.

A considerable body of work has established core principles and practices of educational justice and transformative leadership. Brown (2006) presents research focused on preparing educational leaders to be reflective about political and emancipatory activism; her work is driven by frames of adult and transformative learning theory (as per Mezirow, 1997) with research findings suggesting that practitioner attitudes can be shaped toward socially just educational practices and beliefs. Shields (2004; 2013) posits that transformative educational leaders are called on not only to facilitate academic achievement for all students but to create contexts that nourish the "strong relationships [that] are at the heart of educational equity" (2004, p. 110). Kose (2011) looks at the principal's role in developing transformative school visions; essential to this reality are the coordinated elements of building a shared mission, transformative hiring practices, and curriculum development. Nagda, Gurin, and Lopez (2003) uncovered core essences of engaged learning - they speak of citizenship, public democracy, and critical inquiry, lending a pivotal voice to the argument that understanding the perspectives of others' social issues leads us toward a transformed democracy. Many others join this chorus of voices, arguing that we can work to enact social justice within schools through exemplary leadership that helps us see the necessity for change and "helps us make the realities of change happen” (Theoharis, 2007, p. 222). Kose's empirically-based transformative framework (2009), Darling-Hammmond's (2002) emphasis on learning to teach for social justice, and Dantley and Tillman's (2005) perspective on moral transformative leadership lead us toward a realization of the multiple voices urging a transformed educational world for students and their leaders (Quantz, Rogers, and Dantley, 1991; Weiner, 2003). The path of inquiry undertaken in this article focuses on how these conceptualizations and pragmatics are undertaken by educational leaders effecting transformative changes for special needs students.

Our belief structure is informed by critical theorists and radical educators. Some keystone thoughts are set by Giroux (1983) who argued that transformative school practices go hand-in-hand with the work of building/reforming a democratic society, particularly for those in oppressed circumstances. Giroux helps us see the historical trajectory of this intention in his explanations about the rejection of orthodox Marxism, critique of capitalism, and ideas 
about domination (2009). We must resist delving too deeply here, stating simply that his overview of such ideas leads us directly to an appreciation of related intentions with such educators as Freire (1970), Gramsci (1971) and Foucault (1980). Friere speaks of an oppressive education that is dehumanizing, reducing students to docile, uncritical and passive "marginals" who are indoctrinated within a "banking system" that oppresses them. By contrast, he writes of a liberating education, one that engages students in acts of dialogic consciousness - of people reflecting on their lives in the world in order to transform them. Not unrelated, it was through Gramsci that the term "cultural hegemony” gained popularity as a term denoting the power of a capitalist state to keep its workers contained; he worked intensely to establish the rights of workers to be educated and he sought such advantages for them in the local contexts of his native Italy. In league, Foucault's writings critiqued social institutions and have become fundamental to educational discourse that champions the rights of those often at the fringes of institutional norms of society. These simple characterizations establish the rudiments of a thought structure that inspires the current work of transformative educators influenced by their formative endeavors. It is to some of this work that we turn now, before drawing the radius of this review to a focus on transformative leaders of special needs students.

All students need leadership that fights for their fair shot at the advantages of a broad-based education. Many who are deprived of this fullness - who are edged out of an emancipatory education (Friere, 1970) or access to critical literacy (Shor, 1996) or a solid reading and writing curriculum (Au \& Raphael, 2000) - need voiced representation from school leaders who will challenge, critique and otherwise counter the structure of oppression that deny such opportunities for them especially when they cannot articulate or perhaps even realize such disadvantages for themselves. But the work of leaders of special needs students is perhaps ever more necessary for it may often be these students who can least serve as their own advocates. Quite often, as well, minority students are disproportionately represented within special needs populations (Hosp \& Reschly, 2004) and thus those who work on their behalf realize that they are addressing a complex interplay of cultural, ability, language, and academic variables. The explicitly political work of transformative leaders working with special needs populations is multifaceted, challenging and often overlooked.

Special needs students have much in common with many other segments of the school population who are disadvantaged in terms of academic achievement (Katsiyannis, Zhang, Ryan \& Jones, 2007; O'Donnell, \& White, 2005; Dantley \& Tillman, 2006), cultural inclusion within the norms and values of a "mainstream" school population and curriculum (Delpit, 1988; Marshall \& Oliva, 2006; Cooper, 2009; Brooks, Jean-Marie, Normore, \& Hodgkins, 2007; and Riehl, 2000) and effective leadership for their distinct needs (Theoharis, 2007; Theoharis \& Causton-Theoharis, 2008). Advancing democratic ideals for all students is fundamental to the vision of a just society as Dewey (1916) so convincingly articulated. McLaren (2009) follows in these footsteps in writing about hegemonic practices that deny full participation and access to the rights of a democratically fair education; he says, "hegemony refers to the moral and intellectual leadership of a dominant class over a subordinate class ... through the general winning of consent of the subordinate class” (p. 67). 
For those who administrate programs for special needs students, these ideas are all the more potent.

School leaders are expected to produce high levels of student achievement and schools have placed special needs students into separate programs which have been inadequate in serving their academic needs and have marginalized them from the rest of the student population (Katsiyannis, Zhang, Ryan, \& Jones, 2007; McKenzie et al, 2008; Solórozano, 2008). Despite this trend, transformative leaders have successfully challenged traditional school systems through such practices as inclusion and, in doing so better serving special needs students (Brooks, Jean-Marie, Normore \& Hodgkins, 2007; Theoharis, 2007; Theoharis \& Causton-Theoharis, 2008). However, they have accomplished this largely on their own initiative; for although theorists have discussed transformative leadership at a conceptual level, research focusing on its instruction and practice for special needs leadership has been scant. The force of NCLB (2002) has contributed to tracking special needs students, placing them in separate English language learner and special education programs, retaining them, and decreasing their high school graduation rates (Katsiyannis, Zhang, Ryan, \& Jones, 2007; Solórozano, 2008). Aronowitz (2004) has added that schools have relegated special needs learners to the bottom rungs of the educational system through punishment and disciplinary procedures. It is reasonable to hope that transformative leaders would address these issues in new ways; ways that better meet the needs of these students.

As has been mentioned, the focal direction of this work is toward presentation of an analytic profile of survey and interview responses of leaders who are actively mindful of transformative leadership qualities in their work with special needs students. Heading in this direction we now want to more pointedly highlight some of these constructs and thereby prefigure the twenty-item survey and interview questions, the stems of which contain the prototypic features of transformative leadership. We present such core elements with italicized verb phrases leading readers to proceed to our methodology segment with a focal awareness of the grounding features of transformative leadership as they are embedded in the quantitative survey and qualitative interview items. A review of the literature led us toward a tripartite and relational organization of such leadership features - as firstly Dialogic Change Processes, secondly Revisioning \& Restructuring Acts, and thirdly Relational Dynamics.

In terms of Dialogic Change Processes, Bennis and Nanus (1985) speak of how school leaders discuss their school vision with a range of relevant stakeholders; such a leadership approach is applied by many others (Kose, 2009; Riehl, 2000; Ishimaru, 2013). In a related way, Burns (1978) writes that transformative school leaders support school personnel, enabling them to work together for the common good of the school. The work of Theoharis \& O’Toole, 2011 and Kose, 20011 stands alongside this emphasis. Further, West (1999) emphasizes that transformative school leaders critically self reflect and are mindful of the racial, social and cultural forms of oppression that exit within and outside the school. In this vein McKenzie et al. (2008) asserted that those studying leadership must develop a critical consciousness to uncover discriminatory practices such as racism, classism, sexism, and heterosexism. 
In delineating the categorical focus on Revisioning \& Restructuring Acts, we reference the work of Dyson (2003) who referred to public intellectuals as "paid pests" who disrupt inequitable practices by asking questions and challenging those who advocate for their continued practice. Cochran-Smith (2006) stressed the need to expose the misconceptions related to social and educational justice in school settings, while investigating issues relating to equity and inequity. Cochran-Smith's work urges us toward challenging the abuse of power and privilege in school systems. Cooper (2009) indicated that transformative leaders need to systematically analyze school systems and confront inequities regarding race, class, gender, and ability. Lynch and Baker (2005) and Giroux (1997) insist that such work must entail active application practices while McKenzie et al. (2008) claim that leaders must become social activists who restructure their schools to make them more inclusive in design. Bates (2005) called for schools to redistribute resources and give students access to the materials they need; redistribution relates to the inequalities either in wealth, opportunity, or services that have been present in school systems (as did Rawls, 1971; and North, 2008). O'Donnell \& White (2005) have asserted that school leaders must be a resource provider, and build relationships with various stakeholders, including parents, teachers, and district officials. Most of those cited include active support of high expectations for all students. Further, to counteract over-representation of minority students in special needs programs and allow for full inclusion, school leaders have needed to apply transformative models that deal with both individual and systemic issues (Artiles, Harris-Murri, and Rostenberg, 2006).

As many have no doubt observed, Dialogic Change Processes and Revisioning and Restructuring Acts entail many related variables, as would be expected. Transformative change processes, after all, underlie and support acts of revision and restructuring. Equally critical to transformative leadership effectiveness is the third element of Relational Dynamics that many of the same scholars and researchers aver as fundamental. For example, Burns (1978) wrote that transformative leaders need to act in a moral capacity by elevating their followers and, in turn, being elevated by them. Starratt (1991) suggested that leaders base their practices on the ethics of care, justice, and critique. McCarthy (2005) spoke of the "practiced reflexivity" of leaders who consciously take responsibility for their actions and realize that these have a profound impact on the school community; the work of Mezirow (1997), Dirkx (2001), and Cranton (2002) follows this line of emphasis. Rodriguez, Murakami-Ramahalo, and Ruff (2009) added that leaders who adopt inclusive strategies helped to fulfill the moral obligations of their schools. And Anyon (2005) suggested that school practices have needed to go beyond curriculum, assessment and pedagogy at the macro and micro level, to ameliorate both the systemic problems affecting the educational system and society as a whole. Along these lines Brooks, Jean-Marie, Normore, and Hodgkins (2007) supported Riehl's (2000) thesis about school leaders acting as bridge people within an educational setting. Such work calls for a spirit of dedication that builds communicative relationships with their stakeholders, and makes partnerships with such agencies as schools, colleges, businesses, and social services. Such care entails what some have termed transformative public intellectualism (Giroux, 1997; West, 1999, Dyson, 2003; Cochran-Smith, 2006) in which school personnel engaged in critical dialogue regarding certain systemic issues and then collectively devised a course of action. 
Altogether considered, this review of the scholarship related to transformative leadership gains an applied perspective through the surveys and interviews conducted with administrators of special-needs programs in Southern California. The administrators were interviewed through the survey that was generated on the basis of the many strands of theoretical, research-based and practical work referred to herein. Having set much of that work forth here, we now present core components of the methods through which our study was conducted.

\section{Methodology}

The overall methodological design for this study relied on a mixed methods approach using both quantitative (surveys) and qualitative (audio interviews) tools. A sample population of school leaders responsible for special education programs at the elementary and secondary level rated a list of items describing the characteristics of their work with special needs students; these leaders included assistant principals, principals, district office directors, and special education teachers. Their rating of these items determined the extent of their inclination towards these practices. This characterization offers a broad sketch of the study; further details flesh out how the leaders were selected, how the survey was generated, and how the interview processes were conducted.

Creswell (2007) has defined qualitative research as a process of inquiry that explores a social or human problem conducted in a natural setting. Qualitative researchers have attempted to make sense of phenomena in terms of the meanings people bring to them through the studied use and collection of case studies, personal experiences, and interviews (Denzin \& Lincoln, 2005). Our natural settings were the school sites where purposefully selected participants engaged us through surveys and interviews regarding their views on transformative leadership and how these apply to special education students. All participants responded to a survey derived from the research on transformative leadership practices. Our goal was to determine the extent to which principals and other school leaders apply transformative leadership practices in connection with special needs students at the elementary and secondary level. Related to that was an intention to engage willing participants in interviews that might help us gain a more nuanced view of how and why such practices were valued and applied. We also wondered if gender and/or culturally diversity might have varyingly influenced transformative leadership insights and practices.

\section{Participants}

A purposeful sampling strategy was used to select participants for the first phase of the study (Creswell, 2007). These were individuals whose role as school administrators fit the criteria of the research - those who work with special-needs students and who were engaged in transformative leadership practices. The participants for the first part of the study (i.e. administration of the survey) were 26 elementary and secondary school administrators from various school sites in one particular school district in Southern California, each with at least 
five years of experience at the administrative level and who were actively involved in positions of leadership connected to special education programs and students. The respondents, ranging in age from 39-61, were made up of 10 males and 16 females representing a variety of leadership positions, including two special education teachers, five secondary assistant principals, seven elementary school administrators, nine secondary school principals, one elementary school principal, and two district office directors. All had graduate degrees; 10 self-identified as White, four as African American, 11 as Hispanic/Latino, and one as multi-ethnic.

In the first part of the study, the participants responded to a web-based survey through Survey Monkey. On the survey were 20 items, each ranked on an 8-point Likert scale, ranging from 0 (not at all characteristic of work related to special needs students) to 7 (distinctively characteristic of work related to special needs students) based on transformative leadership practices as found in the literature (and previously reviewed). For the second part of the study, four candidates volunteered to be interviewed; these included an elementary administrator, an elementary school principal, a middle school administrator, and a high school assistant principal. Both the principal and elementary administrators were females; the principal identified herself as White and the elementary administrator as Hispanic/Latino (non-White) on the survey. The middle school administrator and the high school assistant principal were both male and identified themselves as Hispanic/Latino (non-White). A total of four interviews were held with the participants at specific meeting sites throughout the school district. The participants were presented with a set of 10 questions derived from the research on transformative leadership practices (see Table 1 in the Methods section). Each interview was approximately 1-2 hours in duration.

\section{Design of the Measures}

In designing the survey on transformative leadership, prototype analysis was used. Researchers have used prototypes to identify such abstract ideas as emotion, love, and anger for example. People familiar with such concepts may not be able to define them in clear and denotative terms but recognize characteristics of the concepts when they are being exhibited or when they are presented with behavioral or other dimensions of these ideas (Hofsess \& Tracey, 2009; Horowitz and Turan, 2008). For example, love includes a willingness to be with another person; intimacy is demonstrated by a change in mood observed by one who is close to another. It has been typical for researchers to first gather information from experts in the field about what characteristics they believe represent the concept being studied. They have derived a list of key statements from their responses and then placed these in survey form for other participants to rate (Fehr, 2004).

In designing this study, in lieu of querying experts in the field, the key practices of transformative leadership came directly from an exhaustive review of the theoretical and research literature on social and educational justice. The researcher delineated the core elements of this review in a survey format for school administrators to rate, constituting the first part of the study. In the second part of the study, the questions for the interviews were 
derived from these same core precepts. These tables are presented in the results section of this article.

\section{Data Collection and Analysis}

The surveys and audio-taped interviews were collected over a period of 8 weeks. The surveys were completed electronically, and forwarded to the researcher who then contacted those participants who had indicated a willingness to be interviewed. Their interview responses were transcribed and analyzed for themes and patterns through a qualitative case study analysis. Key words and phrases were highlighted, color-coded, then organized in a set of tables for further analysis. The data from the interviews was examined in connection with core transformative leadership practices and its relevance to supporting special needs students. The higher the items were rated on the survey for the first part of the study, the more characteristic they were of transformative school leaders working with special needs learners.

\section{Results}

The table below presents the survey items presented to administrators and also shows the extent to which these core leadership elements are engaged. Further it can be seen that principals are distinguished from "other school administrators". Both groups indicate strong inclinations toward the survey items. Once again, these survey items are derived form a prototypic analysis of core leadership elements are revealed from the literature. This table also provides the quantitative data analysis.

Table 1: Group Statistics - Principals Versus Other Administrators

\begin{tabular}{|c|c|c|c|c|c|}
\hline & \multirow[b]{2}{*}{ Survey Items } & \multicolumn{2}{|c|}{$\begin{array}{l}\text { Principals } \\
\qquad(N=9)\end{array}$} & \multicolumn{2}{|c|}{$\begin{array}{l}\text { Other Administrators } \\
\qquad(N=17)\end{array}$} \\
\hline & & $M$ & $S D$ & $M$ & $S D$ \\
\hline 1. & $\begin{array}{l}\text { To what extent do you discuss with school } \\
\text { personnel your school vision in connection with } \\
\text { special needs students? }\end{array}$ & 5.89 & 1.54 & 4.94 & 1.78 \\
\hline 2. & $\begin{array}{l}\text { To what extent do you work together with school } \\
\text { personnel to improve the functioning of the school } \\
\text { and its programs for special needs students? }\end{array}$ & 6.11 & 1.45 & 5.76 & 1.35 \\
\hline 3. & $\begin{array}{l}\text { To what extent do you engage in critical } \\
\text { self-reflection regarding the requirements of } \\
\text { special needs students? }\end{array}$ & 6.11 & 1.36 & 5.76 & 1.39 \\
\hline 4. & $\begin{array}{l}\text { To what extent do you critically analyze the racial, } \\
\text { social, and cultural forms of oppression that may } \\
\text { exist at your school in connection with special } \\
\text { needs students? }\end{array}$ & 6.00 & 2.00 & 4.88 & 1.41 \\
\hline 5. & To what extent do you ensure that school & 6.33 & 1.41 & 6.12 & 1.22 \\
\hline
\end{tabular}


personnel treat special needs students fairly?

6. To what extent do you investigate issues regarding equity and inequity in connection with special needs students?

7. To what extent do you build relationships with various stakeholders to promote student achievement in connection with special needs students?

8. To what extent do you assist in developing and implementing programs that help to make schools more inclusive for special needs students?

9. To what extent do you assume the role of being a resource provider in connection with special needs

10. To what extent do you assume the role of being an instructional resource for special needs students?

Table 1, continued

\begin{tabular}{|c|c|c|c|c|c|}
\hline & \multirow[b]{2}{*}{ Survey Items } & \multicolumn{2}{|c|}{$\begin{array}{l}\text { Principals } \\
\qquad(N=9)\end{array}$} & \multicolumn{2}{|c|}{$\begin{array}{l}\text { Other Administrators } \\
\qquad(N=17)\end{array}$} \\
\hline & & $M$ & $S D$ & $M$ & $S D$ \\
\hline 11. & $\begin{array}{l}\text { To what extent do you assume the role of being a } \\
\text { communicator for special needs students? }\end{array}$ & 5.78 & 1.64 & 5.82 & 1.29 \\
\hline 12. & $\begin{array}{l}\text { To what extent do you assume the role of being a } \\
\text { visible presence in the school in connection with } \\
\text { special needs students? }\end{array}$ & 6.22 & 1.56 & 6.19 & 1.22 \\
\hline 13. & $\begin{array}{l}\text { To what extent do you assist in implementing } \\
\text { teaching methods and strategies for special needs } \\
\text { students? }\end{array}$ & 6.22 & 0.83 & 6.00 & 1.41 \\
\hline 14. & $\begin{array}{l}\text { To what extent do you develop school programs } \\
\text { that enhance special needs students' personal, } \\
\text { cultural and sociopolitical knowledge? }\end{array}$ & 5.00 & 2.24 & 5.24 & 1.25 \\
\hline 15. & $\begin{array}{l}\text { To what extent do you investigate the impact of } \\
\text { curriculum and assessment on the achievement of } \\
\text { special needs students? }\end{array}$ & 5.89 & 1.45 & 5.47 & 1.59 \\
\hline 16. & $\begin{array}{l}\text { To what extent do you make partnerships with } \\
\text { such agencies as schools, colleges, businesses, and } \\
\text { social services in connection with special needs } \\
\text { students? }\end{array}$ & 5.56 & 1.74 & 4.35 & 1.84 \\
\hline 17. & $\begin{array}{l}\text { To what extent do you reflect on how special } \\
\text { needs students are socialized within a school } \\
\text { setting? }\end{array}$ & 6.00 & 1.41 & 5.24 & 1.30 \\
\hline 18. & To what extent do you challenge the abuse of & 4.89 & 2.20 & 3.35 & 2.55 \\
\hline
\end{tabular}


power and privilege in school systems in

connection with special needs students?

19. To what extent do you encourage individual achievement and serving the public good in connection with special needs students?

20. To what extent do you feel that school programs should focus on liberation, democracy, equality, and justice in connection with special needs students?

Though there are differences between the two groups of administrators in the extent to which the survey items are rated, these differences are not statistically significant. The pattern that emerges from this data shows that principals rate the items somewhat more highly than do other administrators. This pattern is consistent except for items 14, 11, and 9; in these instances the "other" administrators rate such item slightly more highly than do principals but, again, the strength of the difference is not statistically significant.

\section{Qualitative Data Analysis}

This next section will now describe the qualitative data that was collected for this study in the form of interviews conducted at various school sites in the same school district. The researcher decided that a follow-up to the survey from a select number of participants might yield further insights and provide more depth to the study. As was discussed in the quantitative data analysis section, some school leaders may have differing levels of sensitivity and transformative leadership inclination than others based on their positions of leadership (principals and other administrators). The questions for the interviews were derived and summarized from the items listed on the survey, mirroring the practices that were outlined in the literature. For example, the first question which asks, "What are your major roles as a school administrator at your particular site [and] does your role have particular relevance for special needs students?” resembles items 9 through 12 on the survey which ask "In connection with special needs students, to what extent do you assume the role of being a resource provider, an instructional resource, a communicator, a visible presence in the school?” This was done to give the participants an opportunity to elaborate upon these items. Having the responses of this select group provides us a clearer understanding of the prototypical behaviors that transformative school leaders engage in when supporting their special needs learners.

Four out of the 26 participants who completed the survey agreed to be interviewed and provided their contact information. These included an elementary administrator (similar to an assistant school principal), an elementary school principal, a middle school administrator (also an assistant school principal), and a high school assistant principal. Both the principal and elementary administrators were females; the principal identified herself as White and the elementary administrator as Hispanic/Latino (non-White) on the survey. The middle school administrator and the high school assistant principal were both male and identified 
themselves as Hispanic/Latino (non-White).

The following table outlines the questions that were asked of these administrators:

1. a) What are your major roles as a school administrator at your particular site?

b) Does your role have particular relevance for special needs students?

2. What do you see as the ideal classroom-learning environment for special needs students? What elements should be evident?

3. How do you work together with your school personnel to ensure the educational progress of special needs students on a regular basis?

4. What message do you communicate to your staff about how special needs students should be treated?

5. What are your views on equity and inequity in regards to special needs students?

6. How do you work and communicate with your various stakeholders in the school community (parents, teachers, school board members, district officials, etc.) in regard to the educational needs of special needs students?

7. What are your views on inclusion (mainstreaming of students with special needs in regular education classes) and is this being implemented for special needs students?

8. In your role as a school leader, how important is it, in your opinion, to closely examine and shape curriculum and assessment in regards to the educational needs of special needs students?

9. What partnerships have you made with various outside agencies to support student achievement and growth for special needs students?

10. How do you balance your role as an educational leader while, at the same time, investigate issues that pertain to meeting the academic needs of special needs students?

After the interviews were completed, the researcher carefully listened to the responses and transcribed them word for word, including the introduction and the questions, for each set of interviews. These were numbered from one to three, starting with the elementary administrator (Interview \#1, abbreviated "EA" in the transcribed responses), then the elementary school principal and middle school administrator (Interview \#2, abbreviated "EP" and "MSA" respectively), and, finally, the high school assistant principal (Interview \#3, abbreviated “HSAP”).

To organize the data in the most effective way possible, the researcher analyzed the data searching for emerging themes and patterns. This approach allows the researcher to manage, describe, classify, and represent information in a way that makes it easier for both the reader and the researcher to understand and interpret it (Creswell, 2007). It also enables the researcher to create codes based on certain key phrases or words that the participants use in each of their responses and determine particular themes or patterns that emerge from them. 
From these, the researcher can provide descriptions of patterns or themes representing the authentic voices of the participants, and present an in-depth analysis of the data given using tables for greater emphasis. This approach also helps the researcher to draw relevant conclusions in relation to the research question and provide a thorough interpretation of the qualitative data as given.

Once the transcriptions were completed, the researcher read these thoroughly and looked for words and phrases that were repeated often, indicating sensitivity to transformative leadership practices in connection with special needs students. These key words and phrases were put in boldface. Next, particular sections of the responses containing these words and phrases were highlighted using color codes to differentiate them. For example, if the interviewee mentioned anything about "intervention," their response was highlighted in yellow, incorporating the word in boldface. This was the same with other words and phrases such as "response to intervention," "communication," "professional learning communities," "special needs students,” “equity/accommodations,” “mainstreaming/inclusion,” “community,” and "compliance," using several other colors. This enabled the researcher to see if any various themes emerged in the data relating to transformative leadership practices that school leaders employed when supporting special needs students.

A summary of these repeated words, phrases and statements appear in Table 2. These are categorized as "themes;" the statements are shown as "sample statements." After examining interviews 1, 2, and 3 in sequence, both the labels and sample statements roughly appear in the order of responses that the administrators provided for each question. Each speaker is identified with their specific response using the abbreviations as previously described. The design of this table is intended to give readers a "flavor" for the responses provided in terms of what transformative leadership practices these leaders engage in when supporting their special needs students.

Table 2: Interview Themes and Sample Statements

\begin{tabular}{|c|c|}
\hline Themes & Sample Statements \\
\hline \multirow{3}{*}{$\begin{array}{l}\text { Importance of } \\
\text { Intervention Team } \\
\text { Meetings (ITM) } \\
\text { and intervention }\end{array}$} & $\begin{array}{l}\text { EA: "I oversee the intervention team meetings which is the beginning part of when we } \\
\text { start to see when students have needs." }\end{array}$ \\
\hline & $\begin{array}{l}\text { EP: "This particular year, we started our intervention team meeting process. It had } \\
\text { been in previous years a student study team and I felt it was important that we reach out } \\
\text { to all students so that none of them are left without what they need to reach their } \\
\text { potential ..." }\end{array}$ \\
\hline & $\begin{array}{l}\text { HSAP: “. . . and that's why we all work with the teachers is to have patience or find } \\
\text { intervention instead of just sending them out of the class and try to suspend them and } \\
\text { do interventions, call a counselor, call parents, and set up a meeting ...” }\end{array}$ \\
\hline $\begin{array}{l}\text { Importance of } \\
\text { using Response to } \\
\text { Intervention (RtI) }\end{array}$ & $\begin{array}{l}\text { EP: “. . . if we feel it's necessary for either using the RtI model to identify or using } \\
\text { assessment to see if the child qualifies for special education and I feel my role in that } \\
\text { whole process is being the facilitator ...” }\end{array}$ \\
\hline
\end{tabular}


to support student $\quad$ EP: “. . . the response to intervention . . . having them understand the unique needs of success all students if they are going to go to special education or not. Every child has unique needs and we need to look at that ..."

Importance of communication among stakeholders
EA: “. . .if all the correct things are at play everybody is communicating and the staff is working as a team, for example, the administrators with the special education teacher with the special education program and the regular classroom teachers, if that's the case, then equity is obtainable...”

MSA: "We're in the process of making a plan so that we can communicate to teachers what is the process and making sure that they understand there are instructional strategies that they can use to help those students who are having difficulties who are at risk ...”

The value of EP: “. . .making sure that we're having professional learning communities meetings.

Professional

Learning

Communities

(PLCs) to ensure

collaboration

among teachers I have right now, on a weekly basis, in which teachers are looking at data to make sure that the children who are having difficulty have access to the curriculum at their level.” EP: “. . .meeting with the teachers and their PLCs, finding out what they feel their essential standards are and then the pre- and post-tests for each of those essential standards and then assisting the teachers in making sure that the children that are having difficulties [are getting help]”

Administrative strategies for meeting the needs of special education/needs students
EA: “ . . .that . . . we are meeting the goals at the district level, here at the site level, attending board meetings, listening, looking again in regards to special needs students ...”

MSA: “. . .I have meetings with the special education teachers and address concerns; also ... try to be proactive in dealing with parent issues in regards to students receiving the best possible education. .."

HSAP: “. . . making sure that the teacher is also checking for understanding, have proper lesson plans that are geared to special education students, that they're deconstructing the standards and word vocabulary for special education students' understanding. . . “ 
Table 2, continued

\begin{tabular}{ll}
\hline Themes & Sample Statements \\
\hline $\begin{array}{l}\text { Promoting equity } \\
\text { through }\end{array}$ & $\begin{array}{l}\text { EA: "The message I think that our principal that I follow in regards to what his message } \\
\text { is that they are our students. They are students just like everybody else, they are } \\
\text { accommodations } \\
\text { treated just like everybody else ... they should be treated, they need to be treated with } \\
\text { resources }\end{array}$ \\
$\begin{array}{l}\text { equity." } \\
\text { calculators, and educational materials. They also have . . . they are able to be in } \\
\text { classrooms with regular education teachers if they can . . if their disability allows them } \\
\text { to. We're very proactive in making sure that equity is insured." }\end{array}$
\end{tabular}

Promoting a sense

EA: “. . . I was a second year teacher and I took it as an opportunity to be a part of of belonging of mainstreaming an autistic young girl in my classroom. It was an opportunity for me special needs as a classroom teacher and to see the process and be a part of the process and learn what students among it's about, work and support parents that really want to mainstream their child so that the general they can be a part of a regular classroom. ..”

student population through mainstreaming

MSA: “. . .I like to see the student work and I see, okay, if it’s a special day class student, at what point can we start mainstreaming them into the regular education class, so they are learning to be with the mainstream.”

Promoting a

MSA: “ . . .In my school, one of the things that I found is the most essential is

Community of establishing a relationship with my different staff members because we try to do the learners same thing as create a community where the kids are learning but the nitty-gritty is that relationship that you have with individual students. ..”

EP: "You know, a lot of times the parents come back and say "Thank you so much." That totally steers them in a totally different direction than they thought they would ever go and now they have knowledge, now they're being educated, now they're involved in another community in which they're getting support. . .”

Ensuring compliance with legal requirements
EP: "Being in compliance as well. My special education teacher and I talk a lot about the legal issues and making sure that we are in compliance, not just with what is right, but what is legally correct . . . Just doing right by the students by making sure you're in compliance.”

HSAP: “. . .everybody is in compliance with the special needs, the services for the students, and providing any support I can for teachers for their students at the district or state level, more even at the state level.”

Key: EA - Elementary Administrator; EP - Elementary Principal; MSA - Middle School Administrator; HSAP - High School Assistant Principal 
Upon close examination of the coded themes and sample statements, we can see that the school leaders' responses were related to supporting special needs students in a variety of areas where they felt these students were experiencing the greatest challenges. These included classes (intervention), unique needs (Response to Intervention - RtI), forms of instruction (communication), access to the curriculum (Professional Learning Communities PLCs), teacher and parent concerns (special needs students), school access (equity/accommodations), regular education classes (mainstreaming/inclusion), teacher connection (community), and services (compliance). Sample statements from the administrators illustrated the themes that emerged and are presented in Table 2. For instance, in the area of interventions, the high school assistant principal mentioned that

“. . . we all work with the teachers . . . to have patience or find intervention instead of just sending [special needs students] out of the class and try to suspend them and do interventions, call a counselor, call parents and set up a meeting . . .” In regards to RtI, the elementary principal remarked, “ . . . response to intervention [allows us to] understand the unique needs of all students if they are going to go to special education or not. Every child has unique needs and we need to look at that. ...” For communication, the middle school administrator said, "We're in the process of making a plan so that we can communicate to teachers . . . there are instructional strategies that they can use to help those students who are having difficulties who are at risk. . . ." Finally, the elementary administrator said about mainstreaming, “. . . [when] I was a second year teacher [I mainstreamed] an autistic young girl in my classroom. It was an opportunity for me as a classroom teacher [to] be a part of the process and learn what it's about ... so that [special needs children] can be a part of a regular classroom...."

We may surmise from these various examples that transformative leaders, regardless of their position, share similar levels of sensitivity and inclination to transformative leadership practices when it comes to meeting the academic and social needs of special needs students to ensure their success in school. We might also remark that many of the responses for each of the numbered labels relate specifically to the inclusion of special needs students at both the elementary and secondary level. For instance, the elementary principal spoke about the intervention team meeting process (Theme 1) which helped to ". . . reach out to all students so that none of them are left without what they need to reach their potential. . . " The elementary administrator spoke about communication (Theme 3), stating that if, “. . . everybody is communicating and the staff is working as a team, for example, the administrators with the special education teacher . . . and the regular classroom teachers ... then equity is obtainable." The principal also discussed the role of PLCs (Theme 4) in which "... teachers are looking at data to make sure that the children who are having difficulty have access to the curriculum at their level.”

Other statements containing such words and phrases as "special needs students," "access," "mainstreaming," and "community" also relate to how transformative school leaders have attempted to accommodate their special needs learners through inclusive practices. For example, the middle school assistant principal said in reference to special needs students 
(Theme 5) “. . . I have meetings with the special education teachers and address concerns ... in regards to students receiving the best possible education. . . .” For access (Theme 6), the high school assistant principal mentioned, “. . . [the special needs students] have access to all books, transportation, materials, access to buildings, calculators, educational materials. They ... . are able to be in classrooms with regular education teachers if . . . their disability allows them to.” The middle school administrator pointed out for mainstreaming (Theme 7) that, “. . . I like to see the student work and I see ... . at what point can we start mainstreaming them into the regular education class. ...” Finally, in the area of community (Theme 8), the middle school administrator said, “. . . my different staff members [and I] create a community where the kids are learning but the nitty-gritty is that relationship that you have with individual students...."

When comparing responses between the interview subjects, the principal and the elementary administrator shared some similar comments in the categories of communication, PLCs, equity/accommodations, and special needs students. Both believed that communication between the school staff and special education teachers in conjunction with the site administrators was essential. For example, the elementary principal said, "We are all there to support that child and make sure that communication with the parent ... with administration, with the school staff, with the special education teacher . . . and making sure that it's a continuing process." The elementary administrator explained, “. . . if everybody is communicating and the staff is working as a team, for example, the administrators with the special education teacher . . . and the regular classroom teachers . . . then equity is obtainable.”

They also spoke about how as administrators they worked with their respective staffs through professional learning communities to ensure that they were all supporting special needs students. The principal remarked “. . . we're having professional learning communities meetings . . . in which teachers are looking at data to make sure that the children who are having difficulty have access to the curriculum at their level.” The elementary administrator said, "We have what are called professional learning communities almost weekly and our . . . RSP teacher . . . is constantly communicating with teachers at different grade levels because she has students across the spectrum. . ..” In the area of equity, they remarked that special needs students needed to be "treated fairly [and] with respect" (principal) or "with equity" (elementary administrator), regardless of their disabilities, and how important it was to understand and meet their unique needs as effectively as possible.

When comparing the middle school administrator's responses with those of the high school assistant principal, the former provided more details for six out of nine categories than the latter. These comprised of mainstreaming/inclusion, equity/accommodations, RtI, communication, community, and special needs students. The high school assistant principal omitted key statements in the areas of RtI, PLCs, and community. For the first two categories regarding mainstreaming and equity, the middle school administrator described how necessary it was that teachers provide accommodations using appropriate instructional strategies so that special needs students could be more successful in the regular education program. He added that if teachers are “. . . not making accommodations for this one child, 
how are [they] making accommodations for those who are regular education students and who have academic skills at the average level . . . ?” The high school assistant principal gave few specifics in these areas, saying that special needs students had access to learning materials as well as transportation and could be included in the regular education program as much as their disability allowed, but nothing further.

The middle school assistant principal also discussed the importance of using the RtI model and how teachers needed to use a variety of instructional strategies with children who learn differently. He also stressed the importance of creating a community among the school personnel so that they were invested in their students' learning to the fullest extent possible, stating, “. . . the nitty-gritty is that relationship that you have with individual students . . . with staff members to help those individual students." The high school assistant principal spoke about interventions replacing the need for discipline where other individuals such as the parents or the counselor could be involved to help a particular student having difficulty in school. He added that his role as an administrator was "to overlook all of those programs" regarding special needs students and that the "proper policies and procedures of special education needs for our children” were communicated to all school personnel. He also wanted to make sure that "the teacher is also checking for understanding, have proper lesson plans that are geared to special education students," but no information in the areas of RtI or community.

Both secondary school administrators believed that communication was essential between the regular and special education teachers and that the proper policies and procedures regarding the IEP process were understood and followed. The middle school assistant principal felt strongly about how school personnel viewed special needs students and that it was more than just having a set of procedures but "about the human quality, the human understanding; it's about a philosophy ...” when working with these students. The high school assistant principal spoke about compliance and "providing any support I can for teachers for their students at the district or state level." Analyzing these comments further, it would appear that the middle school administrator may have more of an inclination to transformative leadership practices than his high school counterpart. This may be especially true given his comments about the way school personnel should view their special needs learners which show a greater degree of sensitivity. Also, he stressed the need for accommodations, not only for special needs students but also those who are unidentified in regular education classes that could benefit from a variety of instructional strategies.

Comparing the responses at both the elementary and secondary level, the elementary principal addressed all of the issues in explicit detail, ranging from mainstreaming all the way to special needs students. The one area that was incidental and did not relate to inclusion was in the community category regarding her efforts in assisting special needs students who were placed in the emotionally and severely disturbed program. She stated that she "[worked] with the parent so that they could go to the parent trainings ... That was a huge community effort with the school, with the teacher, making sure that the parents knew what was out there...." Given her role as a principal, it could be posited that she assumed more responsibility in these areas than did the other school leaders who had more limited roles at their respective school 
sites. The middle school administrator was the only participant who addressed the issue of accommodations, not only for special needs students, but those in the regular education program which he felt would allow both groups of students to be academically successful. All four participants stressed the need for school personnel to communicate with one another when working with special needs students, regardless of their disability or placement.

Professional learning communities seem to play a greater role at the elementary level than at the secondary level. Whereas the secondary school administrators made no mention of these, the elementary school leaders felt that they were vital in addressing the needs of special needs learners and ensuring that they were making academic progress. The elementary principal remarked that she and her staff “... . [made] sure that the children who are having difficulty have access to the curriculum at their level." PLCs seemed to also facilitate more communication among school personnel where, according to the elementary administrator, the staff and the special education teacher met weekly and ensured that interventions were in place to help the students improve academically. Yet, regardless of their various positions or levels, each expressed a deep commitment to helping special needs students and making sure that they were treated fairly, whether it was through intervention, mainstreaming, or RtI practices among others. They wanted their school personnel to understand the importance of working closely with their students and using different strategies to ensure their needs were being met at a variety of levels. This sense of commitment resonates strongly with inclusion and the principles of transformative leadership as reported in the literature.

\section{Alignment of Quantitative and Qualitative Data}

Based on these findings, we can say that there is a strong relationship between the quantitative and qualitative data in regards to the prototypical behaviors of school leaders and their inclination towards transformative leadership practices in connection with special needs students. There are some variations between principals and other administrators, males and females, and Whites and non-Whites, in terms of their relative inclinations to transformative leadership practices in some areas. This is evident in the area of inclusion where female school leaders were more strongly inclined than male administrators as shown in both sets of data. However, because there is very little statistical significance in the quantitative data from the surveys and the qualitative statements of the school leaders in the interviews generally indicate that they share the same amount of sensitivity to these practices, we can say, perhaps, that there are hardly any differences among different groups of school leaders when engaging in transformative leadership practices in regards to special needs students. They all share the same dedication to meeting the needs of this population in a variety of areas at both the elementary and secondary level.

In light of this conclusion, there may be some issues regarding the amount and type of data that was collected for this study. Though the quantitative data represented a variety of school leaders at both the elementary and secondary level in the district, totaling a sample size of 26 participants, only four of the 26 asked to be interviewed as a follow-up to the survey. Among these four, there were no secondary school principals and no males who classified themselves 
as Whites. Many of the conclusions that the researcher has made are based primarily on the quantitative data in conjunction with the qualitative. Without the views of these individuals represented in the qualitative data, it is difficult to show how strong their inclination is to transformative leadership practices compared to those who participated in the interviews. If more participants from the original sample had volunteered to be interviewed, including secondary school principals and White males, this would have yielded results strengthening the conclusions drawn from the data.

In addition, there may have been some bias on the part of the researcher when choosing sample statements from the interviews to describe themes that emerged from analysis of the transcribed interviews as described earlier. However, based on how the researcher designed, collected, and analyzed both sets of data, the results are fairly consistent in illustrating the prototypical behaviors of school leaders and their inclination towards transformative leadership practices when working with special needs students at both elementary and secondary schools. If the researcher decides to conduct a follow-up study, these issues will be addressed and rectified to either reinforce or challenge the results derived from this current study.

\section{References}

Anyon, J. (2005). Radical possibilities: Public policy, urban education, and a new social movement. New York: Routledge.

Aronowitz, S. (2004). Against Schooling: Education and social class. Social Text, 22(2), 13-35.

Artiles, A., Harris-Murri, N., \& Rostenberg, D. (2006). Inclusion as social justice: Critical notes on discourses, assumptions, and the road ahead. Theory into Practice, 45(3), 260-268.

Au, K., \& Raphael, T. (2000). Equity and literacy in the next millennium. Reading Research Quarterly, 35, 170-188.

Bates, R. (2005). Educational administration and social justice. Education, citizenship and social justice, 1(2), 141-156.

Bennis, W., \& Nanus, B. (1985) Leaders, the strategies for taking charge. New York: Harper and Row.

Brooks, J., Jean-Marie, G., Normore, A., \& Hodgkins, D. (2007). Distributed leadership for social justice: Exploring how influence and equity are stretched over an urban high school. Journal of School Leadership, 17(4), 378-408.

Brown, K. (2006). Leadership for social justice and equity: Evaluating a transformative framework and andragogy. Education Administration Quarterly, 42, 700-745. http://dx.doi.org/10.1177/001316X06290650. 
Burns, J. (1978). Leadership. New York: Harper and Row.

Cochran-Smith, M. (2006). Teacher education and the need for public intellectuals. The New Educator, 2, 181-206.

Cooper, C. (2009). Performing cultural work in demographically changing schools: Implications for expanding transformative leadership frameworks. Educational Administration Quarterly, 45(5), 694-724.

Cranton, P. (2002). Teaching for transformation. New Directions for Adult Learning and continuing education, 93, 63-71.

Cresswell, J. (2007). Qualitative inquiry \& research design: Choosing among five traditions. Thousand Oaks, CA: Sage Publications.

Dantley, M., \& Tillman, L. C. (2006). Social justice and moral transformative leadership. In C. Marshall \& M. Olivia (Eds.), Leadership for social justice: Making revolutions in education. New York: Pearson.

Darling-Hammond, L. (2002). Learning to teach for social justice. New York: Teachers College Press.

Delpit, L. (1988). The silenced dialogue: Power and pedagogy in educating other people's children. Harvard Educational Review, 58, 280-298.

Denzin, N., \& Lincoln, Y. (2005). The discipline and practice of qualitative research. In N. Denzin \& Y. Lincoln (Eds.), The sage handbook of qualitative research ( $3^{\text {rd }}$ edition). Thousands Oaks, CA: Sage.

Dewey, J. (1916). Democracy and education. New York: The MacMillan Company.

Dirkx, J. (2001). The power of feelings: Emotion, imagination, and the construction of meaning in adult learning. New directions for Adult Learning and Continuing Education, 89, 63-72.

Dyson, M. (2003). Open mike: Reflections on Philosophy, race, sex, culture and religion. New York: Civitas Books.

Fehr, B. (2004). Intimacy expectations in same sex friendships: A prototype interaction-pattern model. Journal of Personality and Social Psychology, 86(2), 265-284.

Foucault, M. (1980). Power and knowledge: Selected interview and other writings. New York: Pantheon.

Freire, P. (1970). Pedagogy of the oppressed. New York: Continuum.

Giroux, H. (1983). Theory and resistance in education: A pedagogy for the opposition. Westport: Bergin \& Garvey.

Giroux, H. (1997). Pedagogy and the politics of hope: Theory, culture and schooling. 
Boulder, CO: Westview Press.

Giroux, H. (2009). Critical theory and educational practice. In A. Darder, M. Baltodano, \& R. Torres (Eds.), The critical pedagogy reader. New York: Routledge.

Gramsci, A. (1971). Selections from prison notebooks. New York: International Publishers.

Hofsess, C., \& Tracey, T. (2010). Countertransference as a prototype: The development of a measure. Journal of Counseling Psychology, 57(1), 52-67.

Horowitz, L., \& Turan, B. (2008). Prototypes and personal templates: Collective wisdom and individual differences. Psychological Review, 115(4), 1054-1068.

Hosp, J., \& Reschly, D. (2004). Disproportionate representation of minority students in special education: Academic, demographic, and economic predictors. Exceptional Children, 70(2), 185-199.

Ishimarus, A. (2013). From heroes to organizers: Principals and education organizing in urban school reform. Educational Administration Quarterly, 49(1), 3-51. http://dx.doi.org/10.1177/0013161X12448250

Katsiyannis, A., Zhang, D., Ryan, J., \& Jones, J. (2007). High Stakes testing and students with disabilities: Challenges and promises. Journal of Disability Policy Studies, 18(3), 160-167.

Kose, B. (2009). The principal's role in professional development for social justice: An empirically-based transformative framework. Urban Education, 44, 628-663. http://dx.doi.org/10.1177/0042085908322707

Kose, B. (2011). Developing a transformative school vision: Lessons from peer nominated principals. Education and Urban Society, 43(2), 119-136.

Kozol, J. (1991). Savage inequalities: Children in America's Schools. New York: Crown Publishers.

Kozol, J. (2005). The shame of the nation: The restoration of apartheid schooling in America. New York: Crown Publishing

Lunch, K., \& Baker, J. (2005). Equality in education: An equality of condition perspective. Theory and Research in Education, 3(2), 131-164.

Marshall, C., \& Oliva, M. (2006). Leadership for social justice: making revolutions in education. New York: Pearson.

McKenzie, K., Christman, D., Hernandez, F., Fierro, E., Capper, C., Dantley, M., Gonzalez, M., Cambron-McCabe, N., \& Scheurich, J. (2008). From the field: A proposal for educating leaders for social justice. Educational Administration Quarterly, 44(1), 111-138.

McLaren, P. (2009). Critical pedagogy: A look at the major concepts. In A. Darder, M. Baltodano \& R. Torres (Eds.), The critical pedagogy reader. New York: Routledge. 
Mezirow, J. (1997). Transformative Learning: Theory to practice. New Directions for Adult and Continuing Education, 74, 5-12.

Nagda, R., Gurin, P., \& Lopez, G. (2003). Transformative pedagogy for democracy and social justice. Race Ethnicity and Education, 6(2), 166-191.

North, C. E. (2008). "What Is All This Talk about 'Social Justice'? Mapping the Terrain of Education’s Latest Catchphrase.” Teachers College Record, 110(6), 1182-1206.

O’Donnell, R., \& White, G. (2005). Within the accountability era: Principal's instructional leadership behaviors and student achievement. NASSP Bulletin, 89(645), 56-71.

Quantz, R., Rogers, J., \& Dantley, M. (1991). Rethinking transformative leadership: Towards democratic reform of schools. Journal of Education, 173(3), 96-118.

Rawls, J. (1971). A theory of justice. Cambridge: Harvard University Press.

Riehl, C. (2000). The principal's role in creating inclusive schools for diverse students: A review of normative, empirical and critical literature on the practice of educational administration. Review of Educational Research, 70(1), 55-81.

Rodriguez, M., Murakami-Ramalho, E., \& Ruff, W. (2009). Leading with heart: urban elementary principals as advocates for students. Educational Considerations, 36(2), 8-13.

Shields, M. (2004). Dialogic leadership for social justice: Overcoming pathologies of silence. Educational Administration Quarterly 40, 109-132. http://dx.doi.org/10.1177/0013161X03258963.

Shields, M. (2013). Transformative leadership in education: Equitable change in an uncertain and complex world. New York: Routledge.

Shor, I. (1996). When students have power: Negotiating authority in a critical pedagogy. University of Chicago Press.

Starratt, R. (1991). Building an ethical school: A theory for practice in leadership. Educational Administration Quarterly, 27(2), 185-202

Theoharis, G., \& Causton-Theoharis, J. (2008). Oppressors or Emancipators: Critical dispositions for preparing inclusive school leaders. Equity and Excellence in Education, 41(2), 230-246.

Theoharis, G., \& O’Toole, J. (2011). Leading inclusive ELL: Social justice leadership for English language learners. Educational Administration Quarterly, 47(4), 647-688. http://dx.doi.org/10.1177/0013161X11401616

Theoharis, G. (2007). Social justice educational leaders and resistance: Toward a theory of social justice leadership. Educational Administration Quarterly, 43, 221-258. http://dx.doi.org/10.1177/0013161X06293717

West, C. (1999). The Cornel West reader. New York: Civitas. 


\section{Copyright Disclaimer}

Copyright reserved by the author(s).

This article is an open-access article distributed under the terms and conditions of the Creative Commons Attribution license (http://creativecommons.org/licenses/by/3.0/). 